\title{
Adsorption of Zinc on Cassava Peels Activated Carbon and Kaolin Clay: Kinetics, Thermodynamics and Optimization Studies
}

\author{
Ezemokwe David Ekekwe, Chukwujindu Christian Nnabuike and Chukwujindu Kelechi Chibuzo
}

Materials and Energy Technology Department

Projects Development Institute

Enugu, Nigeria

\begin{abstract}
Zinc in industrial, agricultural and domestic effluents gets into the human system and becomes toxic upon accumulation. The kinetics, thermodynamics and optimization of the process parameters for the adsorptions of zinc from zinc chloride ( $\mathrm{ZnCl2}$ ) simulated aqueous effluent using cassava peels activated carbon and kaolin clay were investigated. Proximate and oxide analyses carried out on the raw peels and the clay showed that the peels had $45 \%$ fixed carbon and the clay had more than $2 \%$ oxides of calcium, magnesium and iron in addition to alumina and silica. Whereas activated carbon was produced from the peels by carbonization at $700^{\circ} \mathrm{C}$ for 2 hours in a muffle furnace, and subsequent treatment with phosphoric acid at $800^{\circ} \mathrm{C}$ for 2 hours, the clay was not modified. The adsorption data generated at different levels of contact time were modeled and the pseudo-second-order kinetics model was adequate for the kinetics of the system at room temperature with regression coefficient $(R 2)$ of 0.998 . The adsorption data also fitted into Langmuir, Freundlich and Temkin isotherms with a monolayer adsorption capacity of $4.8 \mathrm{mg} / \mathrm{g}$ and $3.1 \mathrm{mg} / \mathrm{g}$ for the activated carbon and clay respectively. The thermodynamic showed that the adsorption processes were endothermic and the magnitude of the standard enthalpy change showed that the adsorptions on the clay were more of physisorption while the adsorptions on the activated carbon were more of chemisorptions. Equally, the negative standard Gibb's free energy change showed that the processes were spontaneous. Optimization of the process parameters was carried out using the Box-Behnken design of Response Surface Methodology (RSM) and it was analyzed using Design Expert. Linear model was selected with R-squared, Adjusted R-squared and predicted Rsquared values of 0.90, 0.89 and 0.88 respectively. The Analysis of Variance (ANOVA) of the model parameters showed that the effects of the five numeric factors, which are time, temperature, $p H$ dosage and initial concentration, were statistically significant with p-values less than 0.01. It also showed that the effect of the one categorical factor, which is the type of adsorbent (clay or activated carbon), was statistically significant with the p-value less than 0.01. The numerical optimum solutions of the process parameters were obtained with theoretical percentage removal of $88 \%$ and $81 \%$ of zinc on cassava peels activated carbon and kaolin clay respectively.
\end{abstract}

Key Words: Adsorption, Clay, Carbon, Kinetics, Thermodynamics, Optimization.

\section{INTRODUCTION}

Adequate water availability in terms of quantity and quality is essential to human life. Before the advent of industrial revolution, the importance of water from a quantity point of view was of more concern than the quality of water [1]. Civilization, in order to meet up with the needs of the ever-increasing human population triggered different unnatural activities around water bodies. These human activities meant to support agriculture, transportation, industrialization, and for drinking purpose created more concern on the quality of water. Specifically, discharge of toxic industrial wastes and untreated sanitary, dumping of industrial 
Christian Nnabuike et al., Adsorption of Zinc on Cassava Peels Activated Carbon and Kaolin Clay: Kinetics ...

effluent, and runoff from agricultural fields can be the main sources of freshwater pollution [2]. The link between water and diseases has been long established and it became a global problem precisely in the mid nineteenth century [1].

The impurities accumulated in water by human activities may be in both suspended and dissolved form. All metals are soluble to some extent in water and the excessive amount of any metal may present health hazard. Those metals like lead, arsenic, barium, chromium, mercury and silver that are harmful in relatively small amounts are called toxic metals [3]. Zinc is a metal that is required especially in humans as a coenzyme, for wound healing, for DNA synthesis, and generally to maintain good health [4]. However, excess amount of zinc is harmful and toxic to human being [5]. Zinc dissolves in water through industrial, agricultural and domestic processes and when the water is discharged without any treatment, the zinc will directly or indirectly get into the human system and becomes a health hazard upon accumulation.

Adsorption process is said to be the most effective and widely used means of metal removal from waste water. This is basically due to less investment in terms of cost, simple and easy operation [6]. Adsorption involves the use of solid materials known as the adsorbents that have internal pores where the molecules to be removed will be attached. Recently, many waste biomasses, in and outside Nigeria, have been investigated as activated carbon adsorbents for metal and other pollutant removal from water. Nigerian bamboo was said to be effective in zinc removal [7]. The use of activated carbon from bamboo, palm kernel and coco nut shells to remove benzene from effluent was investigated [8]. Cassava peel activated carbon was used for total waste water treatment [9]. The adsorption of copper with Columbian cassava activated carbon was carried out and it was stated that cassava peels activated with $\mathrm{ZnCl}_{2}$ was effective in removal of $\mathrm{Cu}^{2+}$ in aqueous solution [10]. Over 14 million tonnes of cassava peels are produced as waste material in Nigeria [11]. Using cassava peels activated carbon to treat zinc-contaminated water could be of high economic importance owing to the abundance of the peels.

Kaolin is a soft white mineral that has a large array of uses [13]. Kaolin can be found abundantly in Nigeria where it is mainly used for porcelain production and has been investigated and found to be effective in the removal of toxic metals from waste water [14]. It was found to be effective in the adsorption of methylene blue [13], nitrate [15], hexavalent chromium [16], Congo Red [17] from aqueous solution. This report investigated and compared the zinc adsorptive strength of cassava peels activated carbon and raw kaolin clay. The kinetics, thermodynamics and the optimization of process parameters were deemed necessary for the purpose of process design for industrial and large-scale uses.

\section{MATERIALS AND METHOD}

\subsection{Raw materials preparation}

Cassava peels were obtained from Nsukka native home in Enugu State Nigeria. The peels were sun dried, ground to powder and sieved to obtained fine particle of uniform size of $250 \mu \mathrm{m}$ using electromagnetic sieve shaker (BA, 200N model). The kaolin clay was obtained from the Ceramics Department of PRODA in Enugu Nigeria. The clay was ground and sieved to get a uniform particle size used for the experiment. The clay was not treated any further before the adsorption experiment.

\subsection{Proximate analysis of cassava peels}

The proximate analysis parameters and the methods of analyses were according to the American Society for Testing and Materials (ASTMD 5142, 3174, 872 and 3175 for moisture, ash, volatile and fixed carbon respectively) [18]. The methods of the analysis are outlined below:

\subsubsection{The moisture content}

The moisture content of the original cassava peels was determined by weighing $1 \mathrm{~g}$ of the sample using an electronic weighing balance (Model PA 213) in a Petri dish and placing the dish in an oven (DHG-9101-ISA ) at $105^{\circ} \mathrm{C}$ for 1 hour. After which the dish was allowed to cool in desiccators and weighed. Drying in the oven was repeated until a constant weight was obtained. Moisture content was calculated using the formula in (1)

$$
\% \text { moisture }=\frac{w_{2}-w_{3}}{w_{2}-w_{1}} \times 100
$$


Where

$\mathrm{W}_{1}=$ weight of empty crucible

$\mathrm{W}_{2}=$ weight of crucible + sample before heating

$\mathrm{W}_{3}=$ weight of crucible + sample after heating

\subsubsection{The volatile matter content}

The volatile matter content was obtained by heating the moisture free sample with a porcelain crucible in a muffle furnace (SX-512 model) at $900^{\circ} \mathrm{C}$ for $10 \mathrm{~min}$. Heating in the absence of air at high temperature removes the volatile matter only. The volatile matter was calculated using the formula in (2)

$$
\% \text { volatile matter }=\frac{w_{5}-w_{4}}{w_{2}-w_{1}} \times 100
$$

Where

$\mathrm{W}_{5}=$ weight of porcelain crucible + moisture- free sample before heating

$\mathrm{W}_{4}=$ weight of porcelain crucible + sample after heating

$\mathrm{W}_{2}-\mathrm{W}_{1}=$ original weight of sample

\subsubsection{The fixed carbon and ash contents}

The fixed carbon content of the sample was obtained by completely combusting the volatile-free sample with platinum crucible in a Bunsen burner. The residue left was the ash content while the fixed carbon was determined by difference using (3). The percentage ash content was calculated using (4).

$$
\begin{aligned}
& \% \text { fixed carbon }=\frac{w_{7}-w_{8}}{w_{2}-w_{1}} \times 100 \\
& \% \text { ash }=\frac{w_{8}-w_{6}}{w_{2}-w_{1}}
\end{aligned}
$$

Where

$\mathrm{W}_{7}=$ weight of platinum crucible + volatile free sample before heating

$\mathrm{W}_{8}=$ weight of platinum crucible + sample after heating

$\mathrm{W}_{6}=$ weight of empty platinum crucible

$\mathrm{W}_{2}-\mathrm{W}_{1}=$ original weight of sample

\subsection{The Oxide analysis of the kaolin clay}

Following the method described by reference [19], the oxide analysis of the clay was carried out. The clay was digested using a combination of hydrofluoric acid (HF) and aqua ragia as follows: $0.5 \mathrm{~g}$ of the clay was weighed into a Teflon crucible. $5 \mathrm{~mL}$ of aqua ragia was added followed by $15 \mathrm{~mL}$ of $\mathrm{HF}$. The crucible was placed inside the oven at $120^{\circ} \mathrm{C}$ and the clay was allowed to digest until a clear mixture was obtained. The digested clay solution was diluted to $100 \mathrm{~mL}$ with distilled water and filtered using filter paper. The concentration of each of the filtrates determined using Atomic Absorption Spectrophotometer (AAS) (Bulk Scientific 210VGP). Concentration in ppm was converted to percentage using the formula in (5).

$$
\operatorname{conc}(\%)=\frac{\operatorname{Conc}(p p m)}{50}
$$

\subsection{Adsorbents preparation}

The cassava peels powder was carbonized in a muffle furnace (SX-5-12model) at $700^{\circ} \mathrm{C}$ for two hours. After the carbonization the powder was chemically activated with phosphoric acid. The powder was soaked in one molar solution of phosphoric acid and dried at $100^{\circ} \mathrm{C}$ for 2 hours, after which the impregnated powder was carbonized again at $800^{\circ} \mathrm{C}$ for 2 hours. The carbon was washed severally with distilled water until neutral $\mathrm{pH}$ was obtained. The carbon was collected and dried in oven at $120^{\circ} \mathrm{C}$ for 2 hours [20]. The dried adsorbent was ground and kept in a bottle for use as an activated carbon. 
Christian Nnabuike et al., Adsorption of Zinc on Cassava Peels Activated Carbon and Kaolin Clay: Kinetics ...

\subsection{Adsorbate preparation}

A synthetic effluent of Zinc was prepared using Zinc nitrate salt. To prepare a given concentration of the Zinc effluent, the molar mass of the salt was divided by the molar mass of Zinc; the result was multiplied by the gram equivalent of the needed concentration. 10ppm of the Zinc effluent was prepared by dissolving $0.3 \mathrm{~g}$ of Zinc nitrate salt in 1liter volumetric flask and making the flask to the mark with distilled water.

\subsection{The effect of time on the adsorption of zinc and the kinetics models}

To investigate the effect of time on the adsorption of Zinc using the activated carbon and the clay, $0.2 \mathrm{~g}$ of the carbon or clay was weighed into six different $250 \mathrm{ml}$ conical flasks, $20 \mathrm{ml}$ of $10 \mathrm{ppm}$ zinc effluent was added into each of the flask. The flaks were put in a mechanical shaker (model HY-4) and allowed to shake for 10, 20, 30, 40, 50, 60 minutes respectively. The solution was filtered into another set of conical flasks and the concentration of Zinc was measured using atomic absorption spectrophotometer (AAS) (Bulk Scientific 210VGP).

The kinetics model of the adsorption was investigated using the pseudo first and second order kinetic model shown in (6) and (7). Pseudo first order kinetics predicts the system where diffusion through a boundary precedes the adsorption [21].The pseudo second order model was derived on the assumption that the sorption capacity is proportional to the number of active sites occupied on the sorbent [22].

$$
\begin{aligned}
& \text { First order kinetics equation: } \log (q e-q t)=\log q e-\left(\frac{k_{1} t}{2.303}\right) \\
& \text { Second order kinetics equation: } \frac{t}{q_{t}}=\frac{1}{k_{2} q_{e}^{2}}+\frac{t}{q_{e}}
\end{aligned}
$$

Where

qe $=$ adsorption capacity at equilibrium

$\mathrm{qt}=$ adsorption capacity at any time $\mathrm{t}$

$\mathrm{K}_{1}$ and $\mathrm{K}_{2}$ are the pseudo first and second order constants respectively.

\subsection{The effect of adsorbate concentration on the adsorption}

Different concentration of the zinc effluents $(10 \mathrm{ppm}, 20 \mathrm{ppm}, 30 \mathrm{ppm}, 40 \mathrm{ppm})$ were prepared as described in section $2.5 .20 \mathrm{~mL}$ of each of the concentration was added into different conical flasks. $0.2 \mathrm{~g}$ of the adsorbents was also added into the flasks. The flasks were shaken for 60 minutes. After which the solution was filtered into another set of conical flasks. The zinc concentration of the filtrates were determined using AAS. The percentage removal of zinc $(\% \mathrm{R})$ and the adsorption capacity (qt) were calculated using (8) and (9) below [21]:

$$
\begin{aligned}
& \% R=\frac{C_{o}-C_{e}}{C_{o}} \times 100 \\
& q_{t}=\frac{\left(C_{o}-C_{e}\right) \times V}{M}
\end{aligned}
$$

Where

$\% \mathrm{R}=$ percentage removal

$\mathrm{q}_{\mathrm{t}}=$ adsorption capacity $(\mathrm{ppm})$

$\mathrm{C}_{\mathrm{o}}=$ Initial concentration (ppm)

$\mathrm{C}_{\mathrm{e}}=$ Equilibrium concentration $(\mathrm{ppm})$

$\mathrm{V}=$ Volume of effluent $(\mathrm{L})$

$\mathrm{M}=$ mass of adsorbent $(\mathrm{g})$

The adsorption was modeled using different adsorption isotherms as discussed below. 


\subsubsection{Langmuir adsorption isotherm:}

This isotherm was based on different assumptions one of which is that dynamic equilibrium exists between adsorbed gaseous molecules and the free gaseous molecules [23].

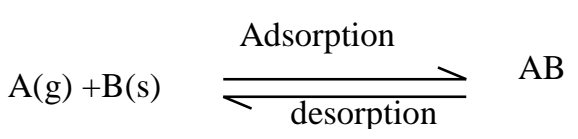

In (10), $\mathrm{A}(\mathrm{g})$ is unadsorbed gaseous molecule, $\mathrm{B}(\mathrm{s})$ is unoccupied adsorbent surface and AB is Adsorbed gaseous molecule.

Based on his theory, Langmuir derived the equation (11) which depicted a relationship between the number of active sites of the surface undergoing adsorption and pressure.

$$
\theta=\frac{K P}{1+K P}
$$

Where $\theta$ the number of sites of the surface which are covered with gaseous molecule, $\mathrm{P}$ represents pressure and $\mathrm{K}$ is the equilibrium constant for distribution of adsorbate between the surface and the gas phase .The basic limitation of Langmuir adsorption equation is that it is valid at low pressure only. Relating the equation to ion adsorption in aqueous solution where $\mathrm{P}$ is analogous to Ce, and $\theta$ is analogous to qe/ql, gives (12) [24],[23],[25].

$$
\frac{C_{e}}{q_{e}}=\frac{1}{q_{l} K_{l}}+\frac{C_{e}}{q_{l}}
$$

where $\mathrm{q}_{\mathrm{l}}=$ monolayer adsoprtion capacity $(\mathrm{mg} / \mathrm{g})$,

$\mathrm{K}_{\mathrm{l}}=$ adsorption constant( $\left.\mathrm{Lit} / \mathrm{mg}\right)$

\subsubsection{Freundlich adsorption isotherm}

In 1909, Freundlich gave an empirical expression representing the isothermal variation of adsorption of a quantity of gas adsorbed by unit mass of solid adsorbent with pressure. This (13) is known as Freundlich Adsorption Isotherm or Freundlich Adsorption equation or simply Freundlich Isotherm [23].

$$
\frac{x}{m}=K P^{\frac{1}{n}}
$$

Where $\mathrm{x}$ is the mass of the gas adsorbed on mass $\mathrm{m}$ of the adsorbent at pressure $\mathrm{p}$ and $\mathrm{k}, \mathrm{n}$ are constants whose values depend upon adsorbent and gas at particular temperature. Though Freundlich Isotherm correctly established the relationship of adsorption with pressure at lower values, it failed to predict value of adsorption at higher pressure. Freundlich isotherm is however, used at low pressure (or concentration) where Langmuir isotherm cannot be used [24].

Application of the equation to adsorption of metal ions in aqueous solution and making it linear yield the following (14) [24],[26]:

$$
\log q_{e}=\log K_{f}+\left(\frac{1}{n}\right) \log C_{e}
$$

Where $\mathrm{K}_{\mathrm{f}}(\mathrm{mg} / \mathrm{g})$ and $\mathrm{n}$ are constants

qe=the equilibrium adsorption capacity $(\mathrm{mg} / \mathrm{g})$

$\mathrm{Ce}=$ equilibrium concentration $(\mathrm{mg} / \mathrm{L})$ 
Christian Nnabuike et al., Adsorption of Zinc on Cassava Peels Activated Carbon and Kaolin Clay: Kinetics ...

\subsubsection{Temkin isotherm}

This isotherm contains a factor that explicitly taking into the account of adsorbent-adsorbate interactions [27]. By ignoring the extremely low and large value of concentrations, the model assumes that heat of adsorption (function of temperature) of all molecules in the layer would decrease linearly rather than logarithmic with coverage [28]. As implied in (15), its derivation is characterized by a uniform distribution of binding energies (up to some maximum binding energy)

$$
q_{e}=B \ln A+B \ln C_{e}
$$

where $\mathrm{B}=\mathrm{RT} / \mathrm{b}_{\mathrm{T}}$

$\mathrm{T}=\operatorname{temp}(\mathrm{K}) ; \mathrm{R}=8.314 \mathrm{~J} / \mathrm{mol} . \mathrm{K}$.

$\mathrm{b}_{\mathrm{T}}$ is the constant related to the heat of sorption and $\mathrm{A}$ is the equalization binding constant $(\mathrm{L} / \mathrm{mg})$

\subsection{The effect of temperature and the thermodynamics}

The effect of temperature on the adsorption was determined by measuring $0.2 \mathrm{~g}$ of the adsorbents into six different $250 \mathrm{ml}$ conical flasks and $20 \mathrm{ml}$ of $10 \mathrm{ppm}$ zinc effluent was added into the flasks. The flasks were put inside water bath (DK600) with shaker set at $30,40,50,60,70$, and $75^{\circ} \mathrm{C}$ respectively. The flasks were shaken for 60 minutes after which it was filtered and the concentration of zinc was measured using the AAS. The standard free energy $-(\Delta \mathrm{G})^{\circ}$, enthalpy change $(\Delta \mathrm{H})^{\circ}$ and the entropy change $(\Delta S)^{\circ}$ were determined to evaluate how spontaneous and feasible is the adsorption process. These thermodynamic parameters were calculated using (16-19) [29].

$$
\begin{aligned}
& \Delta G^{\circ}=-R T \ln K_{C} \\
& K_{c}=\frac{C_{a}}{C_{e}} \\
& \quad \ln K_{c}=-\left(\frac{\Delta G^{\circ}}{R T}\right)=-\frac{\Delta H^{\circ}}{R T}+\frac{\Delta S^{\circ}}{R} \\
& \quad C_{a}=C_{0}-C_{e} ;
\end{aligned}
$$

Where

$\mathrm{R}=8.314 \mathrm{~J} / \mathrm{mol} . \mathrm{K}$;

$C_{e}=$ Equilibrium concentration $(\mathrm{mg} / \mathrm{g})$

$C_{o}=$ Initial concentration $(\mathrm{mg} / \mathrm{g})$

A plot of $\ln \left(\mathrm{K}_{\mathrm{c}}\right)$ against the inverse of temperature $\mathrm{T}(\mathrm{K})$ gives a straight line where the change in enthalpy $(\Delta \mathrm{H})$ and entropy $(\Delta \mathrm{S})$ are calculated from the slope and intercept respectively

\subsection{The effect of $\mathrm{pH}$ on adsorption}

To investigate the effect of $\mathrm{pH}$ on the adsorption, $0.2 \mathrm{~g}$ of the adsorbents was measured into six different conical flasks containing $20 \mathrm{ml}$ of $10 \mathrm{ppm}$ of the Zinc effluent at different $\mathrm{pH}$. The $\mathrm{pH}$ was adjusted using 1 Molar concentration of $\mathrm{HCl}$ and $\mathrm{NaOH}$. Measurement of the $\mathrm{pH}$ was by the use of a $\mathrm{pH}$ meter (Seven compact $\mathrm{pH} /$ ion S220). The flasks were put in a shaker for 60minutes after which the solution was filtered and the zinc concentration was measured using the AAS.

\subsection{The effect of dosage on adsorption}

The effect of dosage was investigated by measuring different grams of the adsorbents in different conical flasks containing 20ml of $10 \mathrm{ppm}$ Zinc effluent. The flasks were put in a shaker and allowed to shake for 60minutes. After which, the solution was filtered and the zinc concentration was measured using the AAS 
International Journal of Advances in Scientific Research and Engineering (ijasre), Vol 4 (2), February-2018

\section{RESULTS AND DISCUSSION}

\subsection{Proximate analysis result for cassava peels}

The proximate analysis of the cassava peels prior to activation is shown in Table1. The peels were more of volatile matter but it contained an appreciable amount of fixed carbon which is required for adsorption. Analysis carried out so far on cassava peels were more of the nutritive aspect and much have not been done on the proximate based on the fixed carbon content [30]. However, the ash content of $4.8 \%$ was in close agreement with the analysis carried out by [30],[31].

Table 1: Proximate analysis result for cassava peels

\begin{tabular}{cccc}
\hline Moisture (\%) & Volatile (\%) & Fixed Carbon (\%) & Ash (\%) \\
5.60 & 47.1 & 42.5 & 4.8 \\
\hline
\end{tabular}

\subsection{The Oxide analysis result for kaolin clay}

The result of the oxide analysis of the clay is shown in Table2. The results were in close agreement with the oxide analysis of bentonite clay as analyzed by reference [19]. The high percentage of aluminum and silica supports that the substance is clay. Moreover, the low contents of metal ions supports that the clay is more of kaolinite [19].

Table 2: The oxide composition of kaolin clay

\begin{tabular}{lccccccccccc}
\hline Oxide & $\mathrm{SiO}_{2}$ & $\mathrm{Al}_{2} \mathrm{O}_{3}$ & $\mathrm{TiO}_{2}$ & $\mathrm{Fe}_{2} \mathrm{O}_{3}$ & $\mathrm{CaO}$ & $\mathrm{MgO}$ & $\mathrm{K}_{2} \mathrm{O}$ & $\mathrm{Na}_{2} \mathrm{O}$ & $\mathrm{P}_{2} \mathrm{O}_{5}$ & $\mathrm{SO}_{3}$ & $\mathrm{I} . \mathrm{L}$ \\
{$[\%]$} & 56.6 & 26.8 & 0.15 & 2.94 & 2.62 & 2.15 & 0.27 & 0.22 & 0.10 & 0.13 & 8.30 \\
\hline
\end{tabular}

\subsection{The effect of time and the kinetic parameters}

From Tables 3 and 4 , it can be seen that the contact time was an important parameter in the adsorption process. Both the percentage removal of zinc ion and the adsorption capacity of the adsorbents were affected by the contact time. The percentage removal and the adsorption capacity increased with the increase in contact time. After 40minutes however, the equilibrium concentration became somewhat constant and consequently percentage removal and the activated carbon increase became insignificant. At this point, the equilibrium was attained. Reference [32] reported that the equilibrium of zinc adsorption on Carica papaya root powder was achieved after 50minutes contact at using $10 \mathrm{mg} / \mathrm{g}$ initial concentration. Table 5 shows the summary of the adsorption kinetic parameters for both the clay and the carbon. It can be seen that both the carbon and the clay kinetics were described by the pseudo second order kinetic model judging by the value of the coefficient of determination $\mathrm{R}^{2}$. The pseudo second order kinetics assumes that the overall sorption rate is limited by the rate of sorbate diffusion in the pores of sorbent(intraparticle diffusion model) [33] .The kinetics parameters agreed with the report by [34], and [32] that zinc adsorption followed pseudo second order kinetics. The fitness of the data into the kinetic models are shown in Figures1and 2.

Table3: The effect of time on Adsorption of zinc using kaolinite clay

\begin{tabular}{ccccccc}
\hline Time(min) & Volume(L) & Mass $(\mathrm{g})$ & $\mathrm{Co}(\mathrm{mg} / \mathrm{L})$ & $\mathrm{Ce}(\mathrm{mg} / \mathrm{L})$ & \%Removal & $\mathrm{qt}(\mathrm{mg} / \mathrm{g})$ \\
\hline 10 & 0.02 & 0.2 & 32 & 15.20 & 52.50 & 1.68 \\
20 & 0.02 & 0.2 & 32 & 12.50 & 60.94 & 1.95 \\
30 & 0.02 & 0.2 & 32 & 11.00 & 65.63 & 2.10 \\
40 & 0.02 & 0.2 & 32 & 8.90 & 72.19 & 2.31 \\
60 & 0.02 & 0.2 & 32 & 8.80 & 72.50 & 2.32
\end{tabular}


Christian Nnabuike et al., Adsorption of Zinc on Cassava Peels Activated Carbon and Kaolin Clay: Kinetics ...

Table4: The effect of time on Adsorption of zinc using cassava peels activated carbon

\begin{tabular}{ccccccc}
\hline Time(mins) & Volume(L) & Mass $(\mathrm{g})$ & $\mathrm{Co}(\mathrm{mg} / \mathrm{L})$ & $\mathrm{Ce}(\mathrm{mg} / \mathrm{L})$ & \%emoval & $\mathrm{qt}(\mathrm{mg} / \mathrm{g})$ \\
\hline 10 & 0.01 & 0.1 & 32 & 13.10 & 59.06 & 1.89 \\
20 & 0.01 & 0.1 & 32 & 11.20 & 65.00 & 2.08 \\
30 & 0.01 & 0.1 & 32 & 8.70 & 72.81 & 2.33 \\
40 & 0.01 & 0.1 & 32 & 6.30 & 80.31 & 2.57 \\
60 & 0.01 & 0.1 & 32 & 5.98 & 81.31 & 2.60 \\
\hline
\end{tabular}

Table5: The kinetic parameters for zinc adsorption on clay and carbon

\begin{tabular}{llll}
\hline Model & Parameter & Clay adsorption & Carbon adsorption \\
\hline Pseudo First order & K1 (min) & 0.073 \\
Pseudo First order & qe calculated $(\mathrm{mg} / \mathrm{g})$ & 3.893 & 2.028 \\
Pseudo First order & qe observed $(\mathrm{mg} / \mathrm{g})$ & 2.320 & 2.650 \\
Pseudo First order & $\mathrm{R}^{2}$ & 0.812 & 0.895 \\
Pseudo second order & K2 (g/mg.min) & 0.030 & 0.048 \\
Pseudo second order & qe calculated $(\mathrm{mg} / \mathrm{g})$ & 2.552 & 2.954 \\
Pseudo second order & qe observed $(\mathrm{mg} / \mathrm{g})$ & 2.320 & 2.650 \\
Pseudo second order & $\mathrm{R}^{2}$ & 0.998 & 0.996 \\
\hline
\end{tabular}

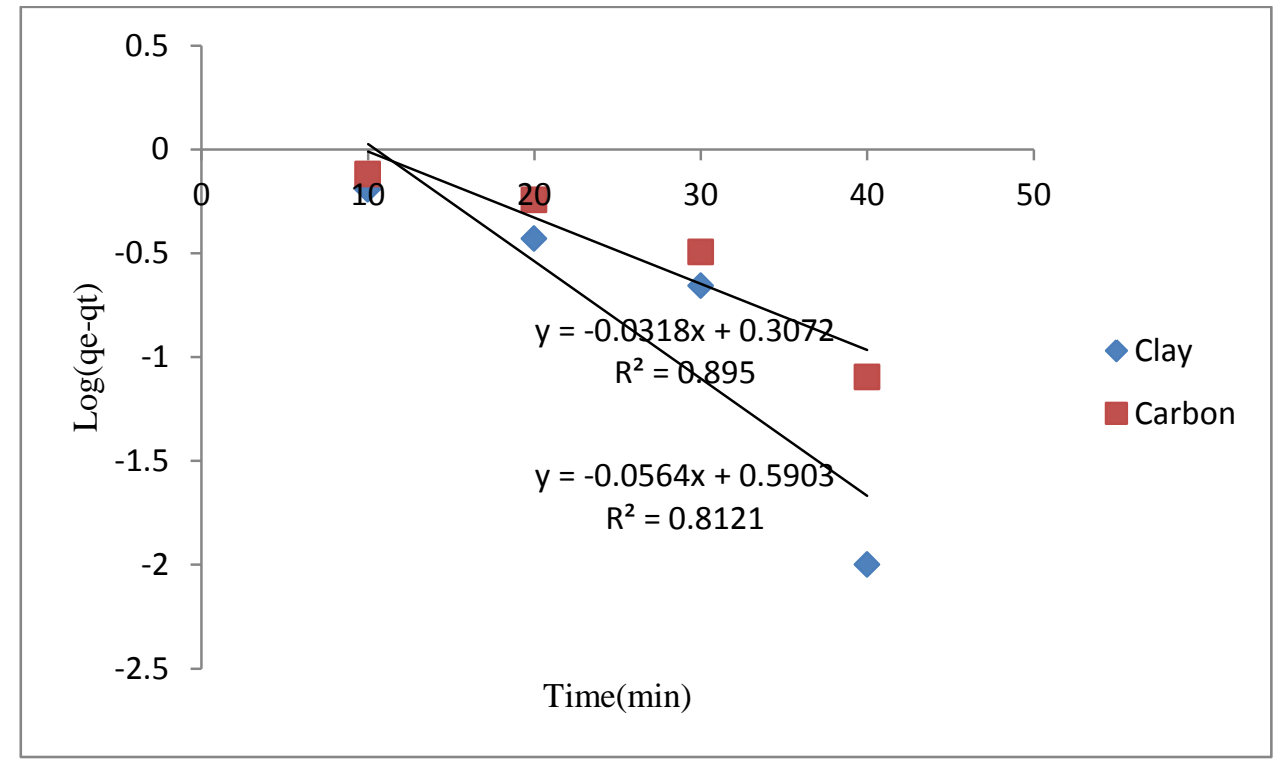

Figure.1: The pseudo first order kinetics for zinc adsorption on at room temperature 


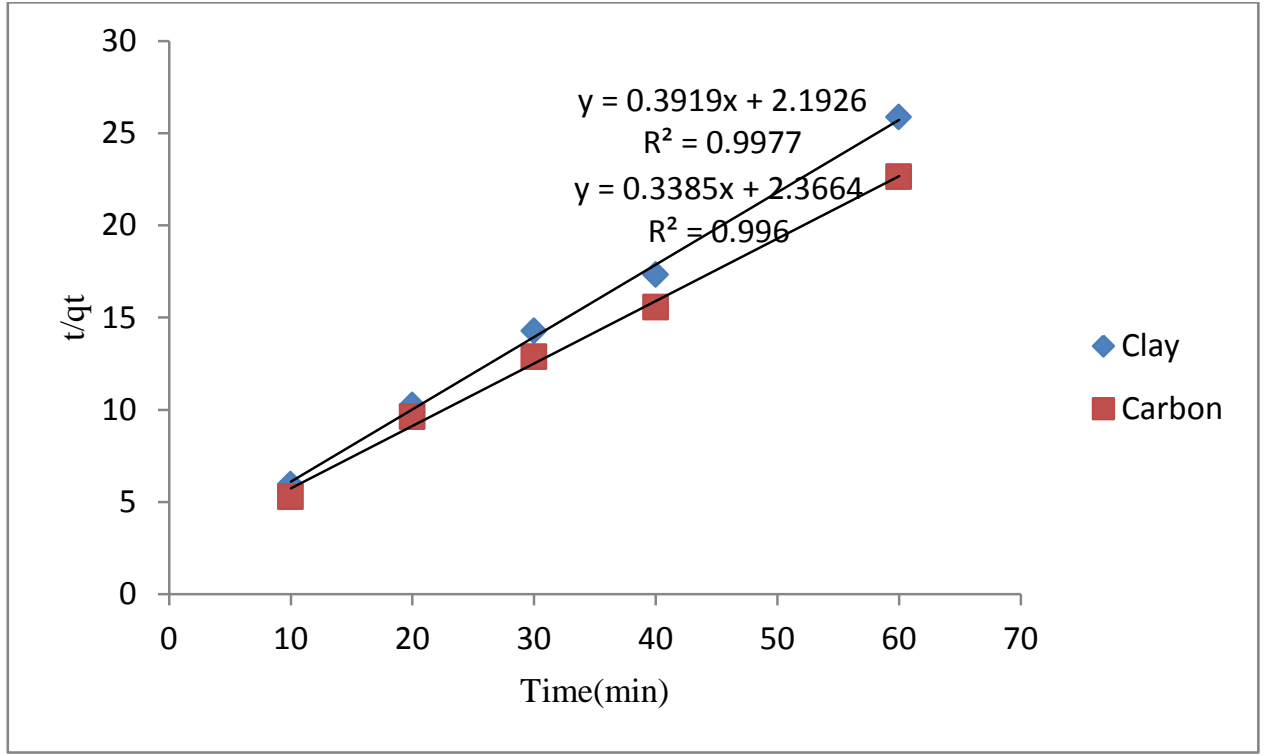

Figure 2: The pseudo second order kinetics for zinc adsorption at room temperature

\subsection{The effect of concentration and the adsorption isotherms}

Tables6 and 7 show that the initial concentration of zinc affected the percentage removal and the adsorption capacity. Whereas there was an inverse relationship between initial concentration and the percentage removal, the relationship between the initial concentration and the adsorption capacity was direct. At initial concentration of 10ppm, clay removed $95.1 \%$ of the zinc at equilibrium with adsorption capacity of $0.95 \mathrm{mg} / \mathrm{g}$ while carbon removed $97.2 \%$ of the zinc with adsorption capacity of $0.97 \mathrm{mg} / \mathrm{g}$. At the initial concentration of $40 \mathrm{ppm}$, clay removed $70 \%$ with adsorption capacity $2.8 \mathrm{mg} / \mathrm{g}$ while carbon removed $90 \%$ with adsorption capacity of $3.6 \mathrm{mg} / \mathrm{g}$. It can be seen from Tables6 and 7 that the activated carbon gave higher adsorption capacity and percentage removal than the kaolin clay.

The summary of the parameters for the different adsorption isotherms is shown in Table8. It can be deduced that Langmuir, Freundlich and Temkin Isotherms provided good fit to the experimental data. The coefficient of determination values $\left(\mathrm{R}^{2}\right)$ were lie between 0.9 and 1.0 which are reasonable for good fitness. The implication is that both the cassava peels activated carbon and the kaolinite clay are microporous solids having relatively small external surface, and the limiting uptake being governed by the accessible micropore volume rather that by the internal surface area [25]. The monolayer adsorption models suggests that the adsorptions were more of chemisorptions [24]moreover, the values of the index $n$ of the Freundlich isotherm being 2.99 and 2.0 for the clay and the carbon respectively indicates that the adsorptions were more of chemisorptions[7]. It was equally observed that zinc adsorption on activated carbon prepared from bamboo followed Langmuir and Freundlich iostherms at room temperature [7]. The adsorption constant $b_{\mathrm{T}}$ of the Temkin isotherm were $4393.8 \mathrm{~J} / \mathrm{mol} . \mathrm{K}$ and $2623.3 \mathrm{~J} / \mathrm{mol} . \mathrm{K}$ for the clay and carbon respectively. Reference [27] reported values of 5305J/mol.K and 5298J/mol.K for adsorption of phosphate on $10 \mu \mathrm{m}$ and $50 \mu \mathrm{m}$ cellulose membrane respectively.

Table6: Effect of initial concentration for adsorption of zinc on clay

\begin{tabular}{cccccc}
\hline $\mathrm{Co}(\mathrm{mg} / \mathrm{L})$ & Volume(L) & mass $(\mathrm{g})$ & $\mathrm{Ce}(\mathrm{mg} / \mathrm{L})$ & \%removal & $\mathrm{qt}(\mathrm{mg} / \mathrm{g})$ \\
\hline 40 & 0.02 & 0.2 & 12.00 & 70.00 & 2.80 \\
30 & 0.02 & 0.2 & 5.90 & 80.33 & 2.41 \\
20 & 0.02 & 0.2 & 1.84 & 90.80 & 1.82 \\
10 & 0.02 & 0.2 & 0.49 & 95.10 & 0.95 \\
\hline
\end{tabular}


Christian Nnabuike et al., Adsorption of Zinc on Cassava Peels Activated Carbon and Kaolin Clay: Kinetics ...

Table7: Effect of initial concnetration for adsorption of zinc on carbon

\begin{tabular}{cccccc}
\hline Co(mg/L) & Volume (L) & mass $(\mathrm{g})$ & $\mathrm{Ce}(\mathrm{mg} / \mathrm{L})$ & \%Removal & $\mathrm{qt}(\mathrm{mg} / \mathrm{g})$ \\
\hline 40 & 0.01 & 0.1 & 4.00 & 90.00 & 3.60 \\
30 & 0.01 & 0.1 & 2.10 & 93.00 & 2.79 \\
20 & 0.01 & 0.1 & 1.41 & 92.95 & 1.86 \\
10 & 0.01 & 0.1 & 0.28 & 97.20 & 0.97 \\
\hline
\end{tabular}

Table8: Parameters for different adsorption isotherms of zinc adsorption of clay and carbon

Langmuir adsorption isotherm

$\begin{array}{lcc} & \text { Clay } & \text { Carbon } \\ \mathrm{ql}(\mathrm{mg} / \mathrm{g}) & 3.058 & 4.847 \\ \mathrm{Kl}(\mathrm{L} / \mathrm{mg}) & 0.794 & 0.633 \\ \mathrm{R}^{2} & 0.998 & 0.910\end{array}$

Freundlich adsorption isotherm

$\begin{array}{lll}\mathrm{N} & 2.991 & 2.009 \\ \mathrm{Kf}(\mathrm{mg} / \mathrm{g}) & 1.306 & 1.778 \\ \mathrm{R}^{2} & 0.961 & 0.976\end{array}$

Temkin adsorption isotherm

$\begin{array}{lcc}\mathrm{b}_{\mathrm{T}}(\mathrm{J} / \mathrm{mol} . \mathrm{K}) & 4392.813 & 2623.286 \\ \mathrm{~A}(\mathrm{~L} / \mathrm{g}) & 11.461 & 8.173 \\ \mathrm{R}^{2} & 0.997 & 0.913\end{array}$

\subsection{The effect of temperature and the thermodynamic parameters}

Tables 9 and 10 show the effect of temperature and the thermodynamic parameters for the adsorption of zinc on clay and carbon respectively. The adsorption capacity and the percentage removal increased with the increase in temperature. The thermodynamic data fitted into the thermodynamic model with the $\mathrm{R}^{2}$ values lying between 0.9 and 1.0 as can be seen in Figure 3 . The values of the change in enthalpy $(\Delta \mathrm{H})$ were positive showing that the process was endothermic. References [35], [36], and [37] reported endothermic process for zinc adsorption on different adsorbents. The $\Delta \mathrm{H}$ for the adsorption of zinc on clay was $15.181 \mathrm{KJ} / \mathrm{mol}$ while that of activated carbon was $77.918 \mathrm{KJ} / \mathrm{mol}$. According to reference [25], values of enthalpy change at $20-40 \mathrm{KJ} / \mathrm{mol}$ shows physical adsorption and values at $40-400 \mathrm{KJ} / \mathrm{mol}$ shows chemisorptions. It means that the zinc adsorption on the kaolinite clay was more of physical adsorption and the bonding force was more of van der waals force while the zinc adsorption on the cassava peels activated carbon was more of chemical adsorption and the binding force was chemical bond. Furthermore, the values of the $\Delta H$ show that adsorption on the clay was reversible and that on the carbon was irreversible. The values of the Gibb's free energy 
change $(\Delta \mathrm{G})$ were negative showing that the adsorption processes were spontaneous. The absolute values of the Gibb's free energy change for the adsorption on carbon were higher than the corresponding values for the adsorption on clay. This means that the adsorption on carbon was more spontaneous. The positive entropy changes $(\Delta S)$ show that the processes were feasible [25].

Table9: Thermodynamics parameters for zinc adsorption on clay

\begin{tabular}{cccccccc}
\hline hTemp & Co & $\mathrm{Ce}$ & $\mathrm{qt}$ & & $-\Delta \mathrm{G}$ & $\Delta \mathrm{S}$ & $\Delta \mathrm{H}$ \\
$\left({ }^{\circ} \mathrm{C}\right)$ & $(\mathrm{mg} / \mathrm{L})$ & $(\mathrm{mg} / \mathrm{L})$ & $(\mathrm{mg} / \mathrm{g})$ & $\%$ Removal & $(\mathrm{J} / \mathrm{mol})$ & $(\mathrm{J} / \mathrm{mol} . \mathrm{K})$ & $(\mathrm{J} / \mathrm{mol})$ \\
\hline 40 & 32 & 13.4 & 1.86 & 58.125 & 731 & \\
50 & 32 & 12.4 & 1.96 & 61.250 & 1240 & 50 & 15181 \\
60 & 32 & 12 & 2.00 & 62.500 & 1748 & \\
70 & 32 & 10 & 2.20 & 68.750 & 2257 & & \\
75 & 32 & 9 & 2.30 & 71.875 & 2511 & & \\
\hline
\end{tabular}

Table 10: Thermodynamics parameters for zinc adsorption on carbon

\begin{tabular}{cccccccc}
\hline $\begin{array}{c}\text { Temp } \\
\left({ }^{\circ} \mathrm{C}\right)\end{array}$ & $\begin{array}{c}\mathrm{Co} \\
(\mathrm{mg} / \mathrm{L})\end{array}$ & $\begin{array}{c}\mathrm{Ce} \\
(\mathrm{mg} / \mathrm{L})\end{array}$ & $\begin{array}{c}\mathrm{qt} \\
(\mathrm{mg} / \mathrm{g})\end{array}$ & $\%$ Removal & $\begin{array}{c}-\Delta \mathrm{G} \\
(\mathrm{J} / \mathrm{mol})\end{array}$ & $\begin{array}{c}\Delta \mathrm{S} \\
(\mathrm{J} / \mathrm{mol} . \mathrm{K})\end{array}$ & $\begin{array}{c}\Delta \\
(\mathrm{J} / \mathrm{mol})\end{array}$ \\
\hline 40 & 32 & 16 & 1.6 & 50 & 735 & & 76734 \\
50 & 32 & 15.5 & 1.65 & 51.56 & 1730 & & \\
60 & 32 & 4.5 & 2.75 & 85.93 & & & \\
70 & 32 & 2.8 & 2.92 & 91.25 & 6662 & \\
80 & 32 & 2.1 & 2.99 & 93.44 & 7895 & \\
\hline
\end{tabular}

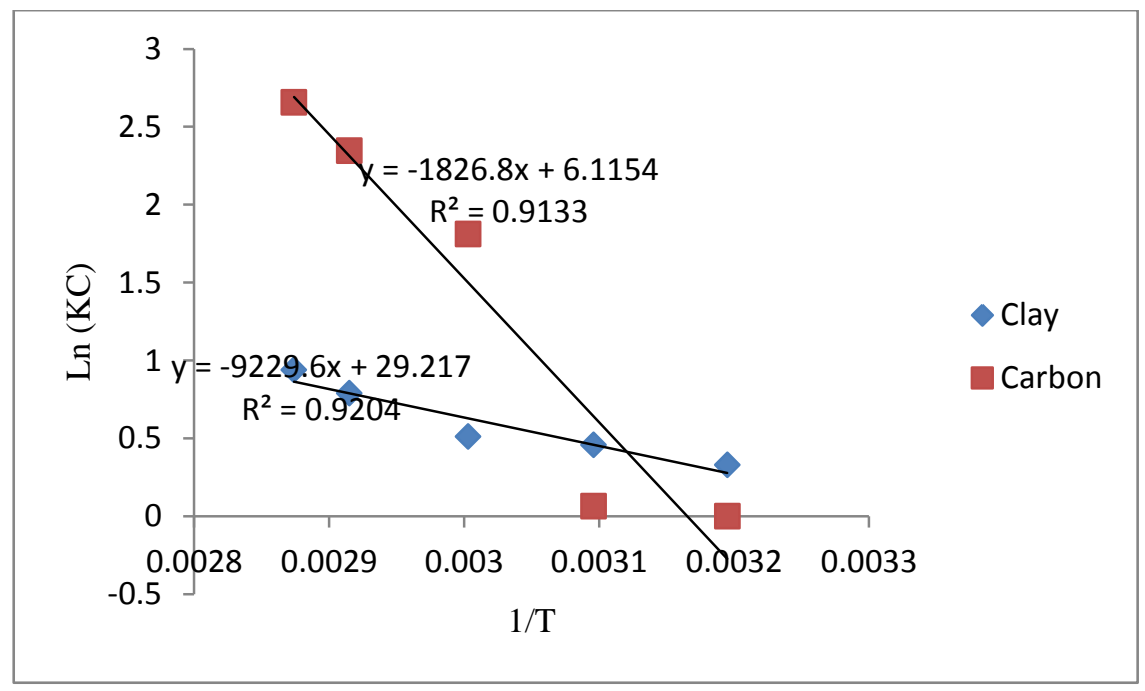

Figure .3: The thermodynamic model for zinc adsorption on clay and carbon 
Christian Nnabuike et al., Adsorption of Zinc on Cassava Peels Activated Carbon and Kaolin Clay: Kinetics ...

\subsection{The effect of $\mathrm{pH}$ on the adsorption process}

Figure 4 shows the effect of $\mathrm{pH}$ on clay and carbon adsorption respectively. The $\mathrm{pH}$ of the solution affected the adsorption capacity and the percentage removal due to surface charges interactions [38]. It can be seen that high adsorption capacity and percentage removal were recorded at $\mathrm{pH}$ around neutral point. The adsorption capacity at the alkaline region were however higher than that at the acidic region. The alkalinity improved the adsorption capacity of clay even beyond the adsorption capacity of carbon. Reference [39] reported that significant removal of zinc, cadmium and copper using clay minerals were recorded at $\mathrm{pH}$ above 6.0.

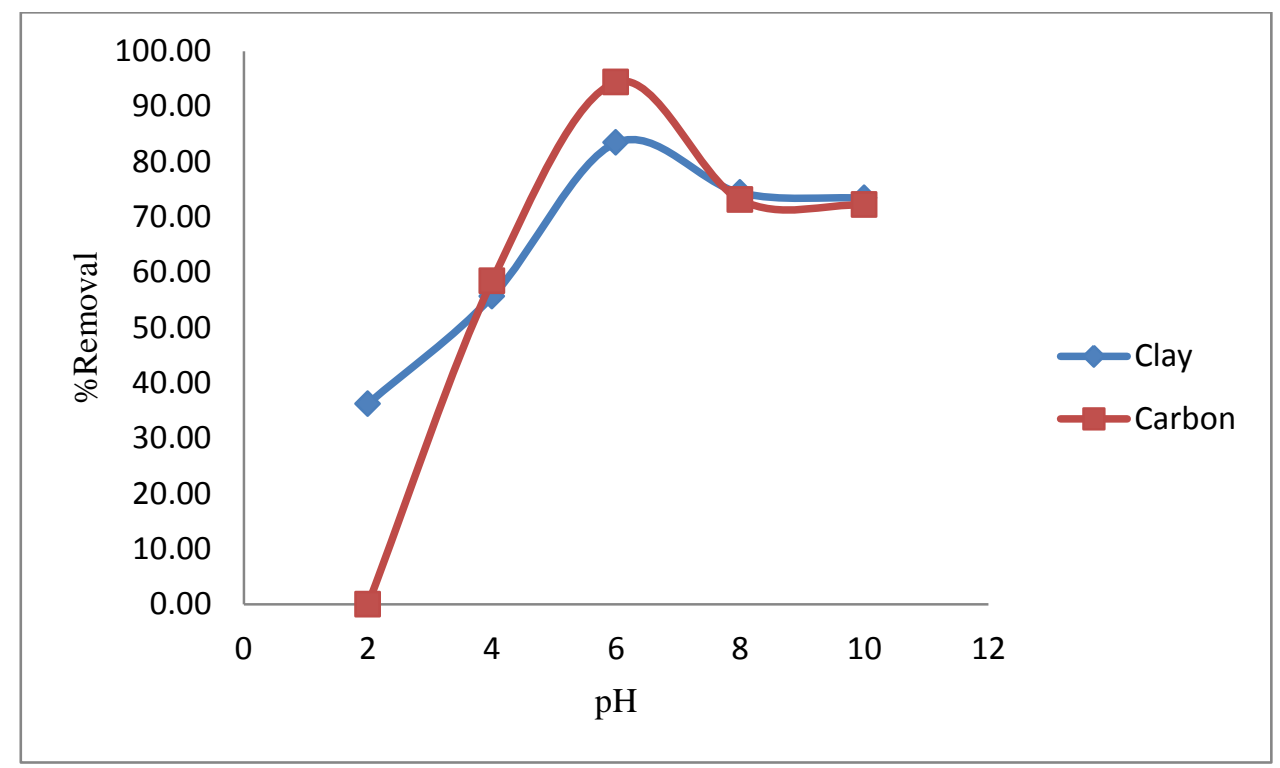

Fig.4: The effect of $\mathrm{pH}$ on zinc percentage removal

\subsection{The effect of dosage on the adsorption process}

It can be seen from Figures5 and 6 that the increase in dosage gave higher increase in percentage removal but the adsorption capacity decreased on both the carbon and the clay. The highest adsorption capacity was obtained with a dosage of $0.1 \mathrm{~g} / 20 \mathrm{~mL}$ but the lowest percentage removal was equally obtained with this dosage. In choosing the best dosage for the rest of the experiment, both the percentage removal and the adsorption capacity were considered and that was the reason behind using the dosage of $0.2 \mathrm{~g} / 20 \mathrm{~mL}$. With $0.1 \mathrm{~g} / 20 \mathrm{~mL}$ dosage, the carbon gave $5.1 \mathrm{mg} / \mathrm{g}$ adsorption capacity while the clay gave $4.54 \mathrm{mg} / \mathrm{g}$ adsorption Capacity. As the dosage increases, the percentage removal increases but the adsorption capacity decreases. However, the increase in percentage removal and the decrease in adsorption capacity became somewhat insignificant beyond a dosage of $0.2 \mathrm{~g} / 20 \mathrm{~mL}$

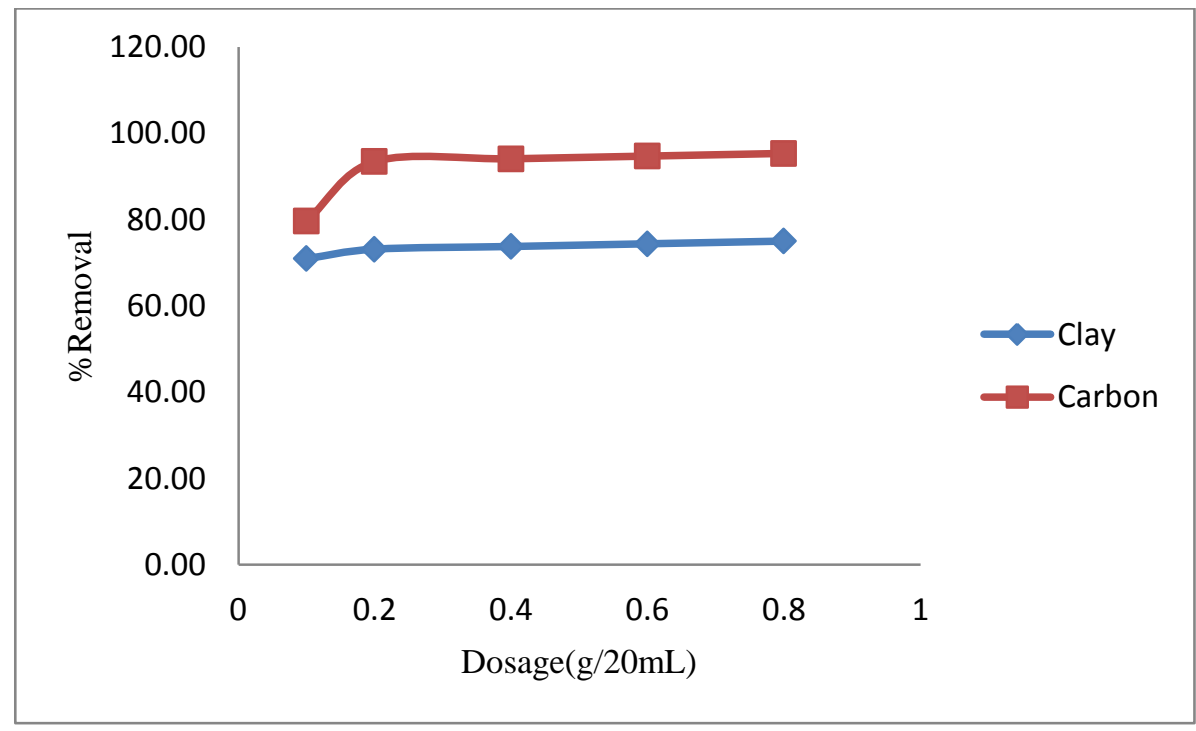

Fig.5: The effect of dosage on percentage removal 


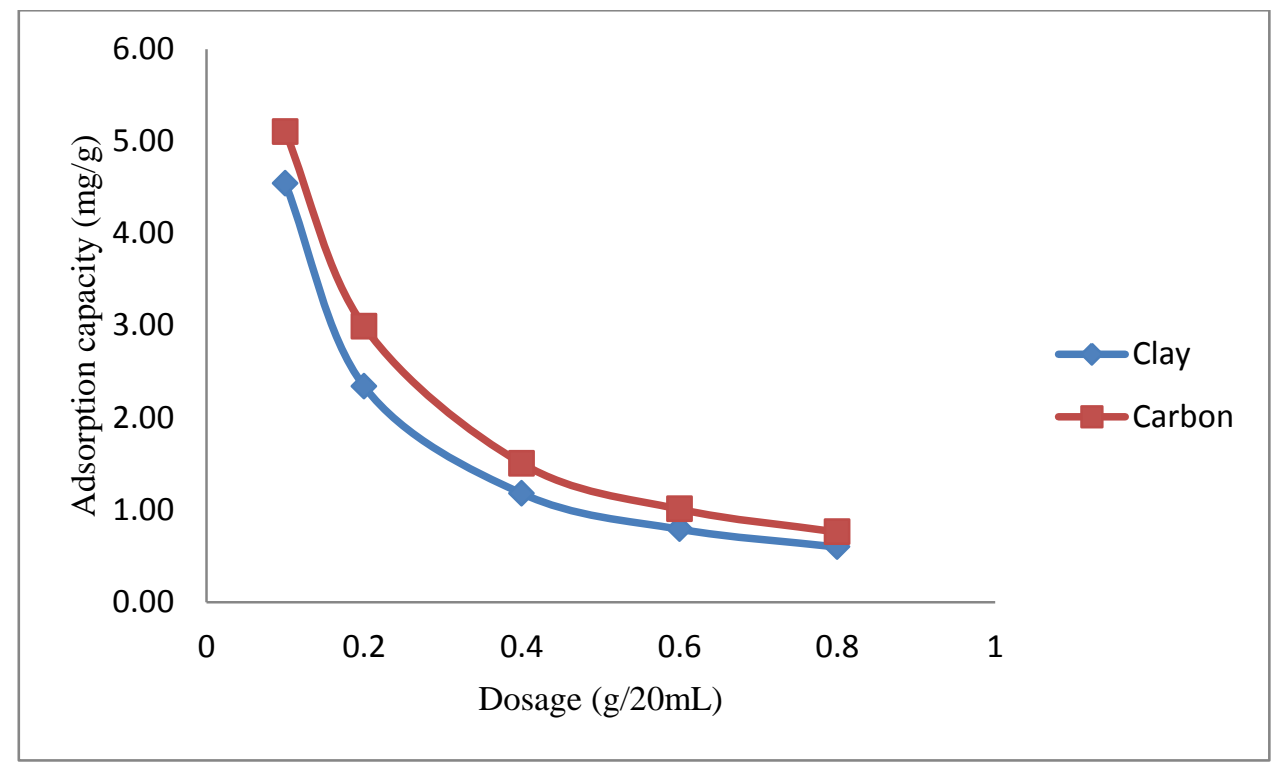

Fig.6: The effect of dosage on adsorption capacity

\subsection{Optimization Study}

The optimization of the process parameters for the adsorption of zinc ions using cassava peels activated carbon and kaolinite clay was carried out using the Box Behnken Design of Response Surface Methodology (RSM). The design parameters are shown in Table11. Using Design Expert (version 6.0.6), a total of 92 runs were generated and the response which is the percentage removal was obtained experimentally. Analysis of the response was also achieved using Design Expert. The Design Expert selected linear model as the adequate model for the system where the percentage removal is the response. The Analysis of Variance (ANOVA) showed that the model, the five numeric factors (time, temperature, $\mathrm{pH}$, dosage and concentration) and the categorical factor (The type of adsorbent) were significant at 0.01significant level. The ANOVA table with the analysis parameters is shown in Table12. The $R^{2}$ value of 0.902 was in reasonable agreement with the predicted $R^{2}$ of 0.895 and the adjusted $R^{2}$ value of 0.883 , which means that linear model is adequate for the system [40]. The linear model equations for the clay and carbon are shown in (20) and (21) respectively. Both equations have positive coefficients for time, temperature, $\mathrm{pH}$ and dosage. The coefficient of concentration in both equations is negative. This means that the overall effect of concentration on the percentage removal was negative. The percentage removal decreased with the increase in the initial concentration of zinc.

Table11: The optimization design parameters

\begin{tabular}{|c|c|c|c|c|c|c|c|}
\hline Factor & Name & Units & Type & $\begin{array}{c}\text { Low } \\
\text { Actual }\end{array}$ & $\begin{array}{l}\text { High } \\
\text { Actual }\end{array}$ & $\begin{array}{c}\text { Low } \\
\text { Coded }\end{array}$ & $\begin{array}{l}\text { High } \\
\text { Coded }\end{array}$ \\
\hline A & Time & Min & Numeric & 10 & 60 & -1 & 1 \\
\hline $\mathrm{B}$ & Temperature & ${ }^{\circ} \mathrm{C}$ & Numeric & 30 & 70 & -1 & 1 \\
\hline $\mathrm{C}$ & $\mathrm{pH}$ & & Numeric & 3 & 8 & -1 & 1 \\
\hline $\mathrm{D}$ & Concentration & $\mathrm{mg} / \mathrm{L}$ & Numeric & 10 & 40 & -1 & 1 \\
\hline $\mathrm{E}$ & Dosage & $\mathrm{g} / 20 \mathrm{~mL}$ & Numeric & 0.1 & 0.8 & -1 & 1 \\
\hline $\mathrm{F}$ & Type of adsorbent & & Categorical & Clay & Carbon & & \\
\hline
\end{tabular}


Christian Nnabuike et al., Adsorption of Zinc on Cassava Peels Activated Carbon and Kaolin Clay: Kinetics ...

Table12: The ANOVA table

\begin{tabular}{|c|c|c|c|c|c|c|}
\hline Source & Sum of & & Mean & $\mathbf{F}$ & & Remarks \\
\hline & Squares & DF & Square & Value & Prob $>$ F & \\
\hline Model & 4186.063 & 6 & 697.6770833 & 129.761 & $<0.0001$ & significant \\
\hline A & 1128.125 & 1 & 1128.125 & 209.8201 & $<0.0001$ & \\
\hline B & 205.0313 & 1 & 205.03125 & 38.13378 & $<0.0001$ & \\
\hline $\mathrm{C}$ & 120.125 & 1 & 120.125 & 22.34206 & $<0.0001$ & \\
\hline $\mathrm{D}$ & 144.5 & 1 & 144.5 & 26.87557 & $<0.0001$ & \\
\hline $\mathrm{E}$ & 52.53125 & 1 & 52.53125 & 9.770292 & 0.0024 & \\
\hline $\mathrm{F}$ & 2535.75 & 1 & 2535.75 & 471.6244 & $<0.0001$ & \\
\hline Residual & 457.0136 & 85 & 5.376630435 & & & \\
\hline Lack of Fit & 455.6803 & 75 & 6.075736715 & 45.56803 & $<0.0001$ & significant \\
\hline Pure Error & 1.333333 & 10 & 0.133333333 & & & \\
\hline Cor Total & 4643.076 & 91 & & & & \\
\hline \multirow[t]{2}{*}{ Std. Dev. } & 2.318756 & & R-Squared & 0.901571 & & \\
\hline & & & Adj R- & & & \\
\hline \multirow[t]{2}{*}{ Mean } & 72.79348 & & Squared & 0.894623 & & \\
\hline & & & Pred R- & & & \\
\hline C.V. & 3.18539 & & Squared & 0.882819 & & \\
\hline
\end{tabular}

\subsection{Mathematical model equations}

$$
\begin{aligned}
& \text { \%Removal (clay) }=50.54+0.23 * \text { time }+0.13 * \text { temp }+0.78 * \mathrm{pH}-0.14 * \text { concentration }+3.66 * \text { dosage } \\
& \% \operatorname{Removal}(\text { carbon })=61.03+0.24 * \text { time }+0.13 * \text { temp }+0.78 * \mathrm{pH}-0.14 * \text { concentration }+3.66 * \text { dosage }
\end{aligned}
$$

\subsection{The numerical optimum solution}

The numerical optimum solution containing the optimum values for the adsorption using clay and carbon is shown in Table13. The optimum percentage removal of zinc using carbon was significantly higher than that of clay. The optimum time was almost the same for both adsorbents. The optimum temperature using clay was higher than that of carbon. Optimum pH using carbon was towards the acidic region while the optimum for the clay was towards the alkaline region. 
Table13: The numerical optimum solution

\begin{tabular}{|c|c|c|c|c|c|c|}
\hline Time(min) & $\operatorname{Temp}\left({ }^{\circ} \mathrm{C}\right)$ & $\mathrm{pH}$ & Concentration(ppm) & Dosage $(\mathrm{g} / 20 \mathrm{~mL})$ & $\begin{array}{c}\text { Type of } \\
\text { adsorbent }\end{array}$ & $\%$ Removal \\
\hline 59.53 & 62.34 & 6.42 & 13.34 & 0.55 & Carbon & 88.1534 \\
\hline 60.00 & 69.44 & 8.00 & 10.10 & 0.70 & Clay & 80.9108 \\
\hline
\end{tabular}

\section{CONCLUSION}

Adsorption of zinc from aqueous solution was achieved using cassava peels activated carbon and untreated kaolinite clay. Factors such as contact time, temperature, $\mathrm{pH}$, adsorbent dosage and initial metal concentration affected the adsorption significantly. The pseudo second order kinetics model provided a good fit to the kinetic data of the adsorption. The Langmuir, Freundlich and Temkin adsorption isotherms also provided good fit to the adsorption at room temperature. The thermodynamic analysis showed that the process was endothermic and spontaneous. The values of the heat of the adsorption suggested that the adsorption with clay was more of physical adsorption while that of carbon was more of chemical adsorption. The optimization study revealed that linear model was adequate for the system using the percentage removal as the response and that the percentage removal of zinc using cassava peels activated carbon was significantly higher than that of kaolin clay.

\section{REFERENCES}

[1] H. S. Peavy, D. R. Rowe, G. Tchobanoglous , Environmental Engineering, McGraw-Hill, Inc,1985, ISBN 0-07-100231-6

[2] H. M. Zwain, M. Vakili, and I. Dahlan, "Waste material adsorbents for zinc removal from wastewater: a comprehensive review". International Journal of Chemical Engineering, 2014, Volume 2014, 13 pages

[3] N.S. Awwad, A.A. El-Zahhar, A.M Fouda., and H.A. Ibrahium, "Removal of heavy metal ions from ground and surface water samples using carbons derived from date pits”. Journal of Environmental Chemical Engineering, 2013, vol. 1, no. 3, pp. 416-423.

[4] H.H. Sandstead, "Understanding zinc: recent observations and interpretations", Journal of Laboratory and Clinical Medicine, 1994, Vol.124, pp. 322-327.

[5] P. Sampranpiboon, P. Charnkeitkong, and X. Feng, "Equilibrium isotherm models for adsorption of zinc (II) ion from aqueous solution on pulp waste". WSEAS TRANSACTIONS on ENVIRONMENT and DEVELOPMENT, 2014, Volume 10

[6] L. T. Markovska, V. D. Meshko and M. S. Marinkovski (2006) "Modeling of the adsorption kinetics of zinc onto granularactivated carbon and natural zeolite". J. Serb. Chem. Soc.2006, 71(8-9) 957-967

[7] F.T Ademiluyi, Alex Abidde, "Batch adsorption kinetics of zinc ions using activated carbon from waste Nigerian bamboo". International Journal of Engineering and Applied Sciences (IJEAS), 2016,Volume-3, Issue-1

[8] J.G. Akpa and C.G.J. Nmegbu, "Adsorption of benzene on activated carbon from agricultural waste materials". Research Journal of Chemical Science, 2014, Vol. 4(9)

[9] I.R. Ilaboya, E.O. Oti, G.O. Ekoh and L.O. Umukoro, "Performance of activated carbon from cassava peels for the treatment of effluent wastewater". Iranica Journal of Energy \& Environment, 2013, 4 (4): 361-375

[10] J.C. Moreno-Piraján and L. Giraldo "Adsorption of copper from aqueous solution by activated carbons obtained by pyrolysis of cassava peel". Journal of Analytical and Applied Pyrolysis, March 2010, Volume 87, Issue 2, Pages 188-193 
Christian Nnabuike et al., Adsorption of Zinc on Cassava Peels Activated Carbon and Kaolin Clay: Kinetics ...

[11] P. Karaimu, "From food waste to animal feed, cassava peels potentially big business for Nigerian women". ILRI News, 2015, www.ilri.org

[12] O.O. Olayiwola, "Economic of cassava peel activated carbon in treatment of effluent from cassava processing industry". International Monthly Refereed Journal of Research in Management \& Technology, 2013, Volume II

[13] D. Ghosh and K. GBhattacharyya (2002) "Adsorption of methylene blue on kaolinite". Applied Clay Science, 2012, Volume, 20, Issue 6,Pages 295-300

[14] F. A. Dawodu and K. G. Akpomie, "Simultaneous adsorption of Ni(II) and Mn (II) ions from aqueous solution unto a Nigerian kaolinite clay". Journal of Material Research and Technology, 2014, 3(2) 129-141

[15] M. Mohsenipour, S. Shahid,and K. Ebrahimi, "Nitrate adsorption on clay kaolin: batch tests". Journal of Chemistry, 2015, Volume 2015, 7 pages

[16] D. Lin, Z. Shi, L. Luo, S. Chen, L. Yang, X. Yang and L. Liu, "Adsorption of hexavalent chromium onto kaolin clay based adsorbent". Journal of Central South University, 2014, Volume 21, Issue 10, pp 3918-3926

[17] M. A. Zenasni, B. Meroufel, A. Merlin and B. George, "Adsorption of Congo red from aqueous solution using CTABKaolin from Bechar Algeria". Journal of Surface Engineered Materials and Advanced Technology 2014, $332-341$

[18] D. Özçimen "An Approach to the characterization of biochar and bio-oil" International Biochar Initiatives, 2013

[19] N. Stanković, M. Logar, J. Luković, J. Pantić, M. Miljević, B. Babić, and A. Radosavljević-Mihajlović (2011) "Characterization of bentonite clay from "Greda" deposit". Processing and Application of Ceramics, 2011, 5 [2] 97-101

[20] N. Salahudeen, C.S. Ajinomoh, S.O. Omaga And C.S. Akpaka, "Production of activated carbon from cassava peel" Journal of Applied Phytotechnology in Environmental Sanitation, 2014, 3 (2): 75-80

[21] K. Mahmoudi, N. Hamdi, E. Srasra, "Preparation and characterization of activated carbon from date pits by chemical activation with zinc chloride for methyl orange adsorption". J. Mater. Environ. Sci.2014, 5 (6)1758-1769

[22] F. H.Scott, Elements of Chemical Reaction Engineering , $3^{\text {rd }}$ Edition, Prentice Hall of India New Delhi, 2006, pp68-108

[23] "Adsorption Isotherm" Chemistry Learning,2009, Retrieved from http://www.chemistrylearning.com/adsorptionisotherm/

[24] R. J.Sime, Physical Chemistry; methods, techniques and experiments, Holt Rinehart \& Winston December 17, 1989, Retrieved from http//www.infohost.nmt.edu.

[25] P. Zhang, "Adsorption and Desorption Isotherms", KC Group, 2016, Retrieved from http//www.keresearchgroup.com.

[26] Adsorption Isotherm, Virtual Amnita Laboratories University Education, 2011, Retrieved from www.vlab.amnita.edu

[27] G. Nechifor, D.E. Pascu, M. P. Neagu, G. Alinatraistaru, P. C. Albu, "Comparative study of Temkin and Flory-Huggins isotherms for adsorption of phosphate anion on membranes". U.P.B. Sci. Bull., 2015, Series B, Vol. 77, Iss. 2, 2015

[28] A.O. Dada, A.P. Olalekan, and A.M. Olatunya, "Langmuir, Freundlich, Temkin and Dubinin-Radushkevich isotherms studies of equilibrium sorption of Zn2+unto phosphoric acid modified rice husk", IOSR Journal of Applied Chemistry (IOSR-JAC), Volume, Issue 1(Nov. -Dec. 2012), PP 38-45

[29] A.L. Myers, "Thermodynamics of adsorption in porous materials". AIChE J., 2002, 48, 145-160

[30] A.A. Lamidi and T. Ogunkunle, "Chemical composition, mineral profile and phytochemical properties of common feed resources used for small ruminant animal production in South-West, Nigeria" I.J.S.N., 2015, VOL.6(1) 92-96

[31] C. E. Okpako, V. O. Ntui , A. N. Osuagwu and F. I. Obasi, "Proximate composition and cyanide content of cassava peels fermented with Aspergillus niger and Lactobacillus rhamnosus" Journal of Food, Agriculture \& Environment, 2008, Vol.6(2): 251 - 255 ,

[32] O. Alao, C. J. Ajaelu.and O. Ayeni, "Kinetics, equilibrium and thermodynamic studies of the adsorption of zinc(II) ions on carica papaya root powder". Research Journal of Chemical Sciences, 2014, Vol. 4(11), 32-38

[33] W. Plazinski, J. Dziuba, W. Rudzinski, "Modeling of sorption kinetics: the pseudo-second order equation and the sorbate intraparticle diffusivity". Adsorption, 2013, 19:1055-1064

[34] D. A. Fungaro and J. E. A. Graciano, "adsorption of zinc ions from water using 
zeolite/iron oxide composites". Adsorption Science \& Technology,2007, Volume 25 Number 10

[35] N. Abdus-Salam, M.O. Bello, Kinetics," thermodynamics and competitive adsorption of lead and zinc ions onto termite mound". International Journal of Environmental Science and Technology, 2015,Volume 12, issue 11, pp 3417-3426

[36] Z. Hawari, N. Rawajfih, "Equilibrium and thermodynamic analysis of zinc ions adsorption by olive oil mill solid residues". Journal of Hazardous Materials, 2009, Volume 168, issues 2-3

[37] Z. Changhua, "Kinetics, isotherm, and thermodynamic study of adsorption of zinc ions from aqueous solution by use of polyamidoamine dendrimer starch". Research on Chemical Intermediates, 2015, Volume 41, issue 4, pp 2567-2582

[38] R.J. Sanders and M.I. El Eherbawy, "Effect of pH on zinc adsorption equilibria and exchangeable zinc pools in soils". Journals of Environmental Pollution, 1983, Volume 44, Issue 3 pp165-176

[39] R.R. Frost and R.A. Griffin, "Effect of $\mathrm{pH}$ on adsorption of copper, zinc, and cadmium from landfill leachate by clay minerals". Journal of Environmental Science and Health, 1977, volume 12, issue 4-5

[40] H. M. Raymond, C. M. Douglas, and A.M. Christine, Response Surface Methodology: Process and Product Optimization Using Designed Experiments, Third Edition, John Wiley \& Sons, Inc, 2009 